\title{
Response of Soybean to Halosulfuron Herbicide
}

\author{
V. K. Nandula, ${ }^{1}$ D. H. Poston, ${ }^{2}$ K. N. Reddy, ${ }^{3}$ and K. Whiting ${ }^{4}$ \\ ${ }^{1}$ Delta Research and Extension Center, Mississippi State University, Stoneville, MS 38776, USA \\ ${ }^{2}$ Pioneer Hi-Bred International, Inc., Leland, MS 38756, USA \\ ${ }^{3}$ USDA-ARS Southern Weed Science Research Unit, Stoneville, MS 38776, USA \\ ${ }^{4}$ Delta and Pineland Company, Scott, MS 38772, USA
}

Correspondence should be addressed to V. K. Nandula,vnandula@drec.msstate.edu

Received 18 October 2008; Accepted 29 May 2009

Recommended by Robert J. Kremer

Recently, halosulfuron injury in soybean through off-target movement of halosulfuron when applied to rice fields has been reported. Sulfonylurea-tolerant (ST) soybean varieties have enhanced tolerance for sulfonylurea herbicides and might provide an option for mitigating injury to soybean from halosulfuron drift. Experiments were conducted to evaluate the effect of halosulfuron on growth and yield of selected soybean varieties with ST trait alone and stacked with glyphosate resistance trait. Soybean plants were treated with halosulfuron at $0,0.0043,0.0087,0.017,0.034$, and $0.069 \mathrm{~kg}$ ai/ha rate at the $\mathrm{V} 3$ growth stage in the greenhouse and at $0.034 \mathrm{~kg} / \mathrm{ha}$ rate (labeled use rate in rice) in the field studies. All soybean varieties containing the ST trait exhibited some halosulfuron injury, but survived the halosulfuron application in the greenhouse. In field studies, a single POST application of halosulfuron at $0.034 \mathrm{~kg} / \mathrm{ha}$ to soybean at three-trifoliolate leaf stage or at full bloom stage resulted in halosulfuron injury to a certain extent regardless of ST trait. Halosulfuron did not have a significant effect on yield of ST varieties compared to their respective nontreated controls. Severe halosulfuron injury in two non-ST varieties resulted in yield loss.

Copyright (c) 2009 V. K. Nandula et al. This is an open access article distributed under the Creative Commons Attribution License, which permits unrestricted use, distribution, and reproduction in any medium, provided the original work is properly cited.

\section{Introduction}

Halosulfuron is a sulfonylurea herbicide used to control several broadleaf weeds and nutsedge (Cyperus spp.) in corn (Zea mays L.), grain sorghum (Sorghum bicolor L.), rice (Oryza sativa L.), sugarcane (Saccharum spp.), and cotton (Gossypium hirsutum L.) [1, 2]. In 2006, approximately $7000 \mathrm{~kg}$ of halosulfuron was applied to rice fields in the US [3]. Sixty-four percent of global soybean (Glycine max (L.) Merrill), production area is planted to transgenic glyphosateresistant (GR) soybean with majority in the US, Brazil, and Argentina [4]. An ever-present need to grow food exists to feed an ever-increasing world population. India and China that are the world's leading rice producers [5] and potentially remain the next large-scale adopters of GR soybean technology wherein GR soybean would be cultivated in the proximity of rice. Increasing labor costs in these countries will steer growers toward reliance on herbicides such as halosulfuron for weed management in rice. Recently, several farmers in the southern US have observed halosulfuron injury in soybean through off-target movement of halosulfuron when applied to rice fields (Whiting, personal observation). Off-target movement of herbicides during application can range from 0.01 to $10 \%$ of the applied rate $[6,7]$. Although these drift rates appear to be sublethal, the injury can be severe in susceptible crops, depending on the growth stage. In other research, simulated drift of $12.5 \%$ of the use rate of $0.84 \mathrm{~kg}$ ae/ha glyphosate has injured soybean; however, yields were not affected $[8,9]$.

Sulfonylurea-tolerant (ST) soybean, developed through traditional breeding techniques, has the ST gene, a semidominant trait [10]. The ST soybean varieties have enhanced tolerance for sulfonylurea herbicides and can withstand single or sequential over-the-top applications of selected sulfonylurea herbicides [11-13]. Soybean varieties containing the ST trait might provide an option for mitigating injury to soybean from halosulfuron drift.

The majority of commercially grown soybean varieties in the United States possess the glyphosate resistance trait. Currently, several GR varieties stacked with the ST trait are also available in the market. Such stacked varieties serve as an alternative tool for managing broadleaf weeds resistant to 
glyphosate, and also have the potential to withstand injury from halosulfuron drift from rice fields. However, information on the response of soybean varieties containing both glyphosate resistance and ST traits to halosulfuron is lacking. Therefore, the objective of this research was to evaluate the effect of halosulfuron on growth and yield of selected soybean varieties with ST trait alone and stacked with glyphosate resistance trait. Specifically, the dose-response of soybean varieties to halosulfuron under greenhouse conditions and soybean yield response to label use rate of halosulfuron under field conditions were evaluated.

\section{Materials and Methods}

2.1. Greenhouse Study. Soybean seeds from selected varieties (Table 1) were planted, ten per pot in $10 \mathrm{~cm}$ diameter by $10 \mathrm{~cm}$ deep plastic pots containing a commercial potting mix (Jiffy Products of America Inc., Batavia, Ill, USA). Pots were placed in a greenhouse under natural sunlight conditions. Temperatures during day and night were $25 \pm 4$ and $20 \pm$ $3^{\circ} \mathrm{C}$, respectively. Day length averaged 14 hours through the duration of the experiment. After emergence, plants were thinned to two per pot. Plants were fertilized once with a nutrient solution (Peters Fertilizer Products, W. R. Grace and Co., Fogelsville, Penn, USA) containing $200 \mathrm{mg} / \mathrm{L}$ each of $\mathrm{N}, \mathrm{P}_{2} \mathrm{O}_{5}$, and $\mathrm{K}_{2} \mathrm{O}$ at two weeks after emergence and sub-irrigated as needed. Soybean plants were treated with halosulfuron (Permit 75 DG, Gowan Co., Yuma, Ariz, USA) at $0,0.0043,0.0087,0.017,0.034$, and $0.069 \mathrm{~kg}$ ai $/ \mathrm{ha}$ rate at the growth stage shown in Table 1. The highest single commercial application of halosulfuron in rice is $0.034 \mathrm{~kg} / \mathrm{ha}$ (Buehring, personal communication). A nonionic surfactant (NIS, Induce, Helena Chemical Co., Collierville, Tenn, USA) at $0.25 \% \mathrm{v} / \mathrm{v}$ was added to all the halosulfuron treatments. Herbicide treatments were applied to soybean plants with a moving-nozzle sprayer equipped with $8002 \mathrm{E}$ (Spraying Systems Co., Wheaton, Ill, USA) nozzles delivering 140 L/ha at $240 \mathrm{kPa}$. Soybean injury was estimated on a scale of 0 (no injury) to $100 \%$ (plant death) at 3, 7, 14, and 21 days after treatment (DAT). Fresh weight of live green tissue from plants was recorded 21 DAT. The treatments were arranged as an 11 (variety) by 6 (rate) factorial in a completely randomized design. There were four replications per treatment and the experiment was repeated.

2.2. Field Study. A field study was conducted in 2007 near Stoneville (N $33^{\circ} 22^{\prime} 30^{\prime \prime} \mathrm{W} 90^{\circ} 52^{\prime} 30^{\prime \prime}$ ), Washington County, Miss, USA, on two sites, henceforth referred to as USDA and MAFES that were three miles apart. Prior to the present study, the experimental area on both sites had a history of GR soybean production. Field preparation consisted of disking, subsoiling, disking, and bedding in the fall of 2006.

The USDA site was a Dundee silt loam (fine-silty, mixed, active, and thermic Typic Endoqualf) with pH 6.7, 1.1\% organic matter, a CEC of $15 \mathrm{cmol} / \mathrm{kg}$, and soil textural fractions of $26 \%$ sand, $55 \%$ silt, and $19 \%$ clay. The experimental area was treated with glyphosate (Roundup WeatherMAX 4.5 EC, Monsanto Co., St. Louis, Mo, USA at $0.84 \mathrm{~kg}$ ae/ha on April 30, 2007 to kill existing vegetation. After planting, pendimethalin (Prowl 4 EC, BASF Corp., Research Triangle Park, NC, USA) at $1.12 \mathrm{~kg}$ ai/ha and $S$-metolachlor (Dual 8 EC, Syngenta Crop Protection, Greensboro, NC, USA) at $1.12 \mathrm{~kg}$ ai/ha were applied to provide residual weed control. Clethodim (Select Max 1 EC, Valent USA Corp., Walnut Creek, Calif, USA) at $0.14 \mathrm{~kg}$ ai $/$ ha with a paraffinic petroleum oil adjuvant (Agri-Dex, Helena Chemical Co., Collierville, Tenn, USA) at $0.63 \% \mathrm{v} / \mathrm{v}$ was applied on June 12, 2007 to control grass species. The MAFES site was a Tunica silty clay (clayey over loamy, smectitic over mixed, superactive, nonacid and thermic Vertic Epiaquepts) with $\mathrm{pH} 6.7,2.2 \%$ organic matter, a CEC of $28.7 \mathrm{cmol} / \mathrm{kg}$, and soil textural fractions of $12.7 \%$ sand, $43.4 \%$ silt, and $43.9 \%$ clay. The experimental area was treated at postemergence with clethodim at $0.14 \mathrm{~kg}$ ai/ha plus fomesafen (Reflex $2 \mathrm{EC}$, Syngenta Crop Protection, Greensboro, NC, USA) at $0.35 \mathrm{~kg}$ ai/ha on June 18, 2007 to control grass and broadleaf weeds.

Soybean seed from selected varieties (Table 1) was planted at the USDA and MAFES sites on May 7 and June 5,2007 , respectively, in rows spaced $102 \mathrm{~cm}$ apart. A single application of halosulfuron at $0.034 \mathrm{~kg} / \mathrm{ha}$, highest single commercial application rate, with NIS at $0.25 \%(\mathrm{v} / \mathrm{v})$ was applied postemergence to soybean at 3 rd trifoliolate leaf stage and at full bloom stage (flower in top two nodes) at the USDA and MAFES sites, respectively. Nontreated plots that received all herbicides as described above except halosulfuron were controls. Herbicide treatments were applied with a tractormounted sprayer equipped with TeeJet 8004 (Spraying Systems Co., Wheaton, Ill, USA) standard flat spray nozzles delivering $190 \mathrm{~L} / \mathrm{ha}$ water at $180 \mathrm{kPa}$ at the USDA site and $11002 \mathrm{VS}$ flat spray nozzles delivering $140 \mathrm{~L} / \mathrm{ha}$ water at $230 \mathrm{kPa}$ at the MAFES site. Plots were irrigated on an asneeded basis. Soybean injury from halosulfuron was visually estimated at 3, 7, 14, and $28 \mathrm{DAT}$ as described in the greenhouse study. Plots were harvested on September 19 and 21 , and October 4 and 11,2007, based on varietal maturity at the USDA site and on October 30, 2007 at the MAFES site. Soybean from all four rows of each plot at the USDA site from the middle two rows of each plot at the MAFES site was harvested using a combine and grain yield was adjusted to $13 \%$ moisture. The experiment was set up in a randomized complete-block design with six replications per treatment at the USDA site and as an 11 (variety) by 2 (halosulfurontreated and nontreated) factorial in a randomized completeblock design with 4 replications per treatment at the MAFES site. Plots were $15.2 \mathrm{~m}$ long and $4.1 \mathrm{~m}$ wide. There were 22 treatments comprising 11 soybean varieties that were treated with halosulfuron and respective nontreated controls.

2.3. Statistical Analysis. In the greenhouse study, no significant interaction between experiments and treatments was observed; hence, the data from the two experiments were pooled. Regression analysis determined the effect of halosulfuron rate on growth of soybean. The regression parameters from the response curves of soybean varieties were computed using Sigma Plot (Sigma Plot, version 9.0, Systat Software Inc. Point Richmond, Calif, USA). Due to a 
TABLE 1: Soybean varieties, maturity group, and growth stage at the time of halosulfuron application in greenhouse and field studies.

\begin{tabular}{|c|c|c|c|c|}
\hline \multirow[b]{3}{*}{ Variety $^{\mathrm{b}}$} & \multirow[b]{3}{*}{ Maturity group } & \multicolumn{3}{|c|}{ Soybean growth stage $\mathrm{e}^{\mathrm{a}}$} \\
\hline & & \multirow[t]{2}{*}{ Greenhouse } & \multicolumn{2}{|c|}{ Field } \\
\hline & & & $\mathrm{USDA}^{\mathrm{c}}$ & MAFES $^{\mathrm{c}}$ \\
\hline DP $4112 \mathrm{RR} / \mathrm{S}$ & 4.1 & $30 \mathrm{~cm}$ tall, $\mathrm{V} 3$ & $25 \mathrm{~cm}$ tall, $\mathrm{V} 4$ & $75 \mathrm{~cm}$ tall, $\mathrm{R} 2$ \\
\hline DP $4888 \mathrm{RR} / \mathrm{S}$ & 4.8 & $30 \mathrm{~cm}$ tall, $\mathrm{V} 3$ & $25 \mathrm{~cm}$ tall, $\mathrm{V} 4$ & $75 \mathrm{~cm}$ tall, $\mathrm{R} 2$ \\
\hline DP $4919 \mathrm{RR} / \mathrm{S}$ & 4.9 & $30 \mathrm{~cm}$ tall, $\mathrm{V} 3$ & $25 \mathrm{~cm}$ tall, $\mathrm{V} 4$ & $75 \mathrm{~cm}$ tall, R2 \\
\hline 07-4492 RR/S & 4.9 & $28 \mathrm{~cm}$ tall, $\mathrm{V} 3$ & $25 \mathrm{~cm}$ tall, $\mathrm{V} 4$ & $75 \mathrm{~cm}$ tall, R2 \\
\hline DP 5115 RR/S & 5.1 & $29 \mathrm{~cm}$ tall, V3 & $23 \mathrm{~cm}$ tall, $\mathrm{V} 4$ & $73 \mathrm{~cm}$ tall, $\mathrm{R} 2$ \\
\hline DP 5335 RR/S & 5.3 & $29 \mathrm{~cm}$ tall, V3 & $25 \mathrm{~cm}$ tall, $\mathrm{V} 4$ & $75 \mathrm{~cm}$ tall, R2 \\
\hline DP $4748 \mathrm{~S}$ & 4.7 & $30 \mathrm{~cm}$ tall, $\mathrm{V} 3$ & $28 \mathrm{~cm}$ tall, $\mathrm{V} 4$ & $83 \mathrm{~cm}$ tall, $\mathrm{R} 2$ \\
\hline P 95M90 RR/S & 5.9 & $35 \mathrm{~cm}$ tall, $\mathrm{V} 3$ & $28 \mathrm{~cm}$ tall, $\mathrm{V} 4$ & $83 \mathrm{~cm}$ tall, $\mathrm{R} 2$ \\
\hline AG 4903 RR/S & 4.9 & $30 \mathrm{~cm}$ tall, $\mathrm{V} 3$ & $23 \mathrm{~cm}$ tall, $\mathrm{V} 4$ & $73 \mathrm{~cm}$ tall, $\mathrm{R} 2$ \\
\hline DP $4690 \mathrm{RR}$ & 4.7 & $28 \mathrm{~cm}$ tall, $\mathrm{V} 3$ & $28 \mathrm{~cm}$ tall, $\mathrm{V} 4$ & $83 \mathrm{~cm}$ tall, $\mathrm{R} 2$ \\
\hline DP 5989 & 5.9 & $33 \mathrm{~cm}$ tall, $\mathrm{V} 3$ & $28 \mathrm{~cm}$ tall, $\mathrm{V} 4$ & $83 \mathrm{~cm}$ tall, R2 \\
\hline
\end{tabular}

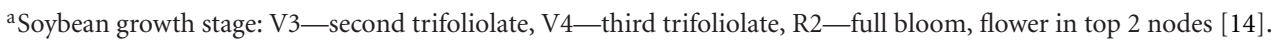

b Abbreviations: AG, Asgrow; DP, DeltaPine; P, Pioneer; RR, Roundup Ready; S, sulfonylurea tolerant.

'Field study locations.

significant experiment (location) effect, data from the field study were analyzed separately by location. A PROC TTEST method using SAS software (SAS Institute, Inc., Cary, NC, USA) was employed to determine if halosulfuron affected soybean yield within individual varieties. Percent yield reduction (change) from halosulfuron treatment compared to its nontreated check was computed for each variety and analyzed by PROC GLM procedure in SAS to compare 11 varieties considering all effects as fixed. Mean of percent yield reduction differences were tested using a Fisher's protected LSD test at $P=.05$.

\section{Results and Discussion}

3.1. Greenhouse Study. All ST-trait containing varieties survived halosulfuron application, regardless of herbicide rate. DP 4690 RR and DP 5989 did not possess the ST trait and succumbed to halosulfuron 21 DAT. Within 3 DAT, DP 4690 RR and DP 5989 exhibited injury symptoms such as chlorosis and reddening of veins on abaxial surface of treated leaves, which are typical of sulfonylurea herbicides. Despite the presence of the ST trait, all ST soybean varieties were marginally injured (chlorotic symptoms that remained on halosulfuron-treated plants up to the point of harvest, 21 DAT; whereas chlorotic symptoms in DP 4690 RR and DP 5989 developed into necrotic symptoms and the terminal growing point died by $21 \mathrm{DAT}$ ). The percent injury from halosulfuron in ST-containing varieties averaged 5 to $10 \%$ 3 DAT, 5 to $19 \% 7$ DAT, 5 to $22 \% 14$ DAT, and 5 to $16 \%$ 21 DAT, across all rates (data not shown).

Influence of halosulfuron on fresh weight accumulation of varieties containing the ST trait 21 DAT could best be described by a three-parameter sigmoidal equation of the form $y=a /\left(1+\exp \left(-\left(x-x_{0}\right) / b\right)\right)$, where $y$ is shoot fresh weight expressed as \% of nontreated control, a is an asymptote, $x_{0}$ is the herbicide rate resulting in a given measure of $y, b$ is the slope of the curve around $x_{0}$, and $x$ the herbicide rate, fitted to the raw data (Figure 1). Shoot fresh weight accumulation in response to halosulfuron rate in DP 4690 RR and DP 5989 followed an exponential decay pattern defined by the equation of the form $y=y_{0}+a e^{-b x}$, where $y$ is shoot fresh weight expressed as \% of nontreated control, $y_{0}$ is the intercept, $a$ is an asymptote, $b$ is the slope of the curve, and $x$ is halosulfuron rate, fitted to the raw data (Figure 1). As halosulfuron rate increased from 0 to $0.069 \mathrm{~kg} / \mathrm{ha}$, shoot fresh weight declined to 41 and $46 \%$ of nontreated control in DP 4690 RR and DP 5989, respectively.

3.2. Field Studies. Data are presented separately by location due to a significant location effect. Location effect was significant due to a combination of factors such as different planting dates (May 7, 2007 at USDA versus June 5, 2007 at MAFES), soil characteristics (Dundee silt loam at USDA versus Tunica silty clay at MAFES), growth stage of soybean at halosulfuron application (V4 at USDA versus R2 at MAFES), and weather patterns during the growing season (Figure 2). For example, a few days after planting soybean on the MAFES site (June 5, 2007), the field conditions were wet due to high amounts of precipitation received from mid-June to mid-July. These wet conditions may have stressed soybean plants and prevented proper development. Furthermore, precipitation in September and October was also above the normal for Stoneville, which affected seed and pod development and delayed harvest.

3.3. USDA Site. All soybean varieties exhibited halosulfuron injury to a certain extent (data not shown). Varieties containing the ST-trait were injured 5 to $8 \% 3$ DAT, 7 to $18 \% 7 \mathrm{DAT}$, and 8 to $14 \% 14 \mathrm{DAT}$, but fully recovered by 28 DAT. The two non-ST varieties, DP 4690 RR and DP 5989, exhibited severe halosulfuron injury; 61 to $72 \% 3$ DAT, 73 to $80 \% 7$ DAT, 72 to $76 \% 14 \mathrm{DAT}$, and 78 to $89 \% 28 \mathrm{DAT}$ (data not shown). Halosulfuron did not have a significant effect on yield of ST varieties compared to their respective 


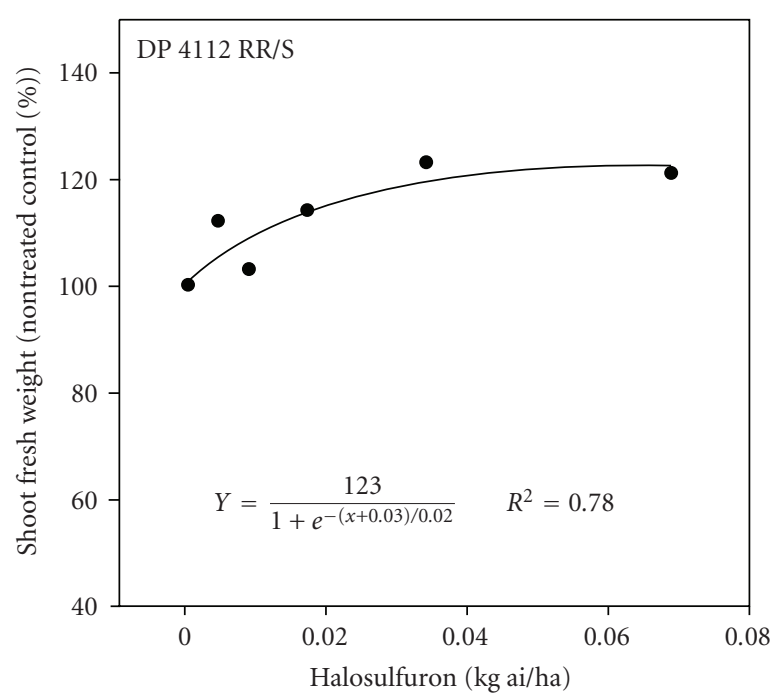

(a)

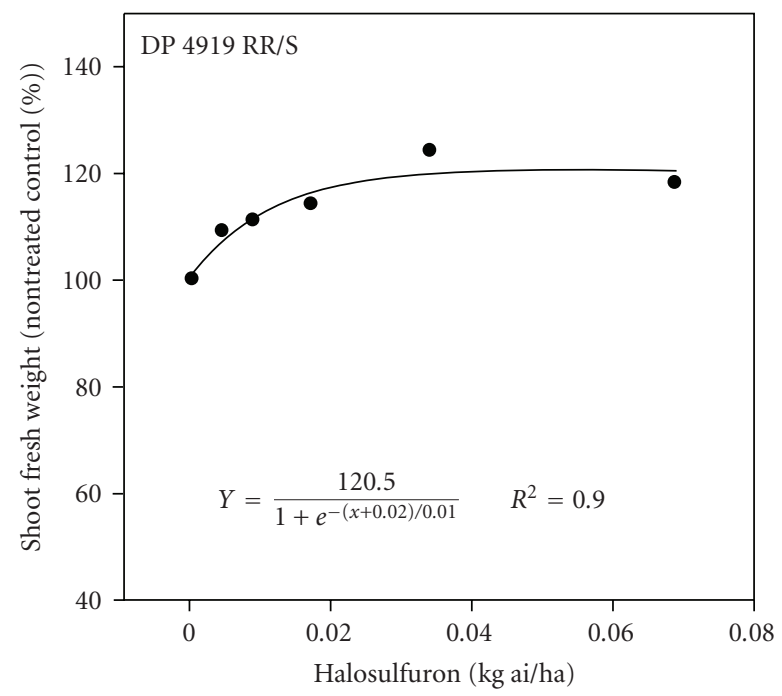

(c)

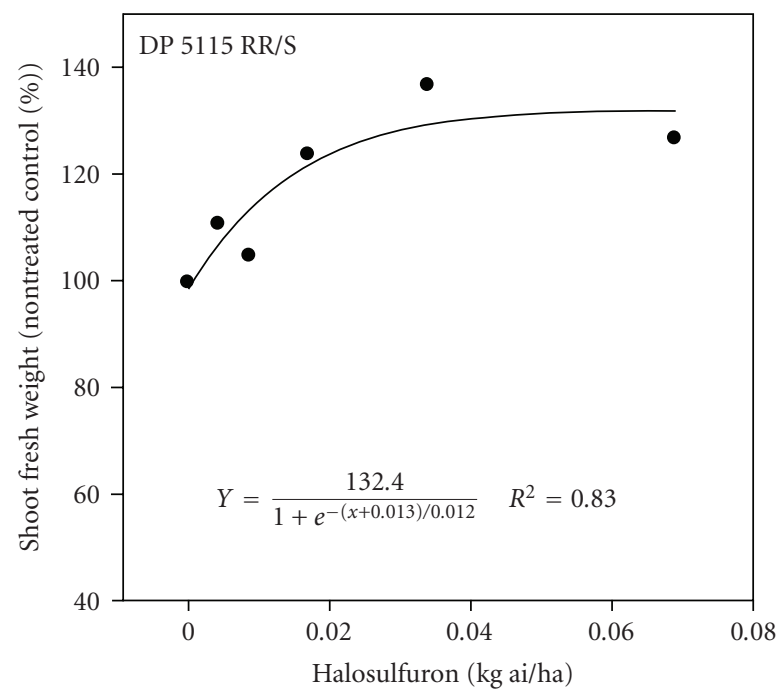

(e)

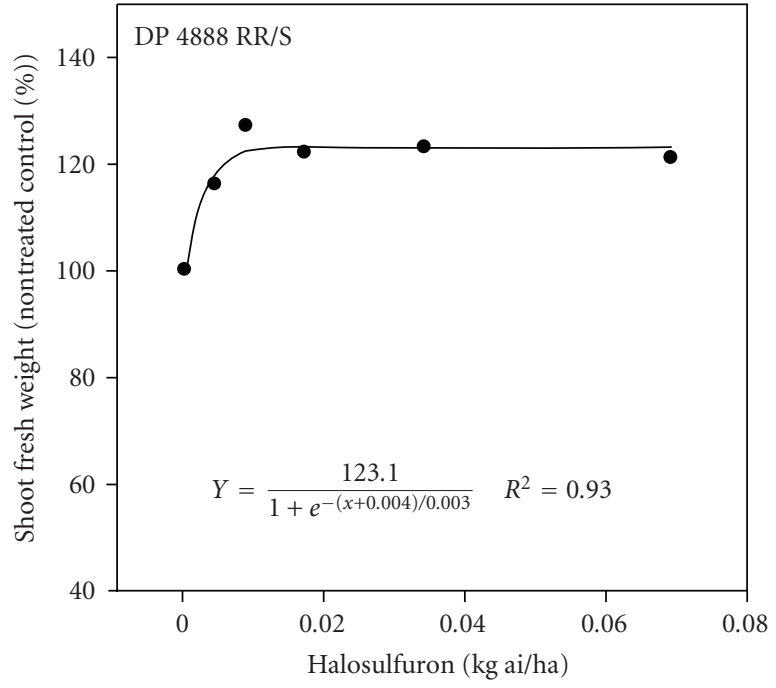

(b)

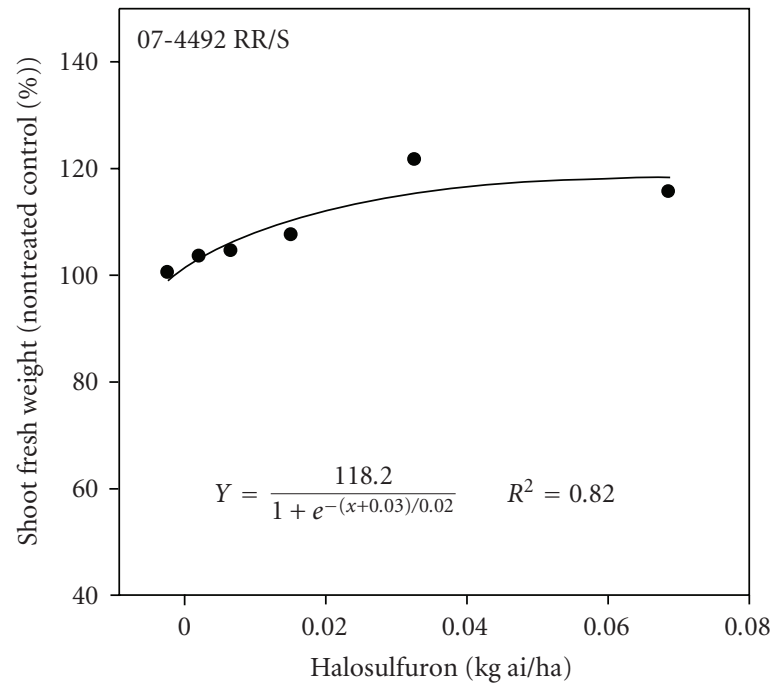

(d)

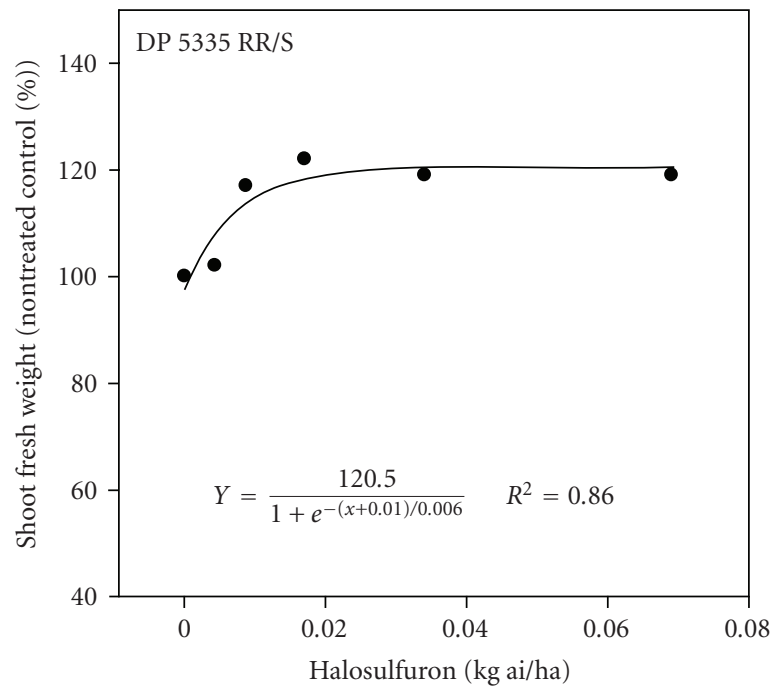

(f)

FIgure 1: Continued. 


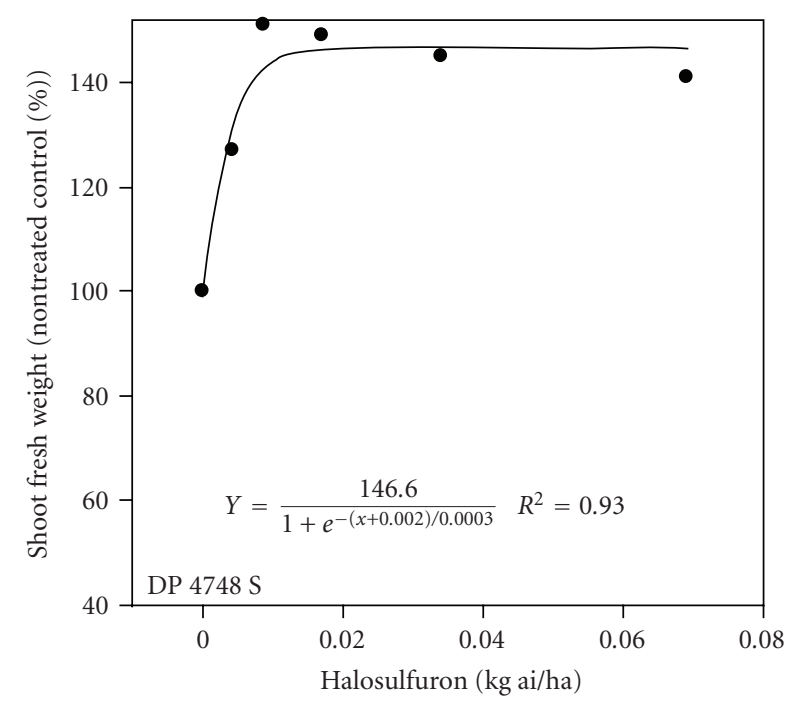

(g)

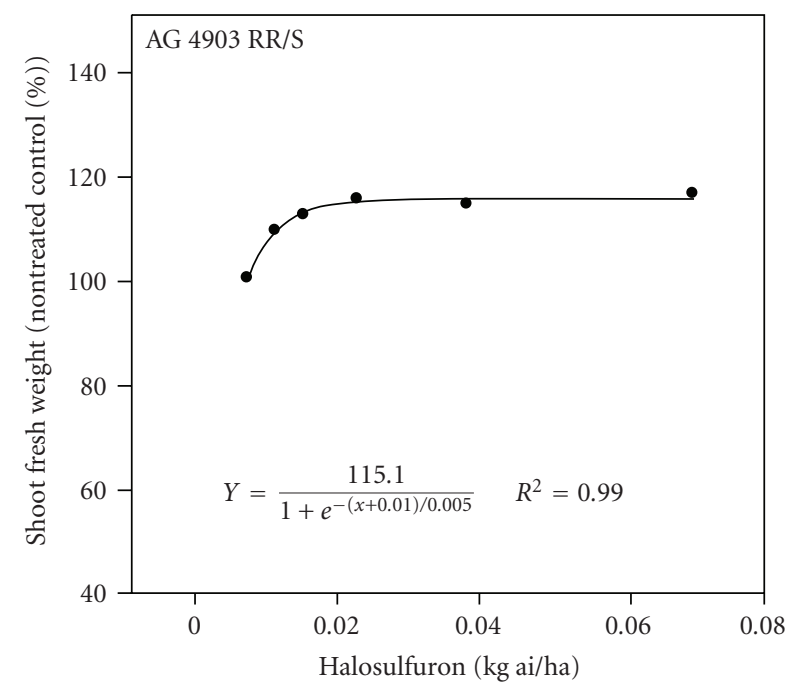

(i)

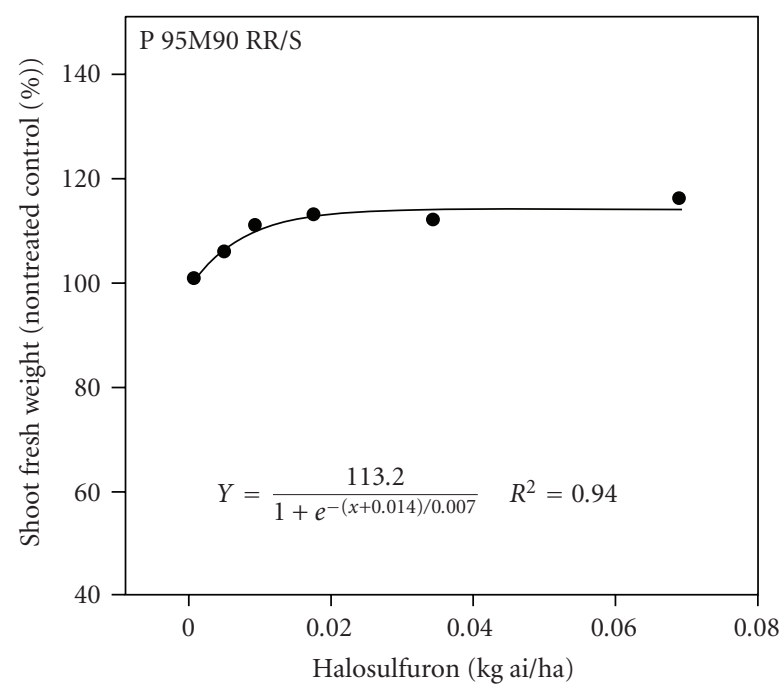

(h)

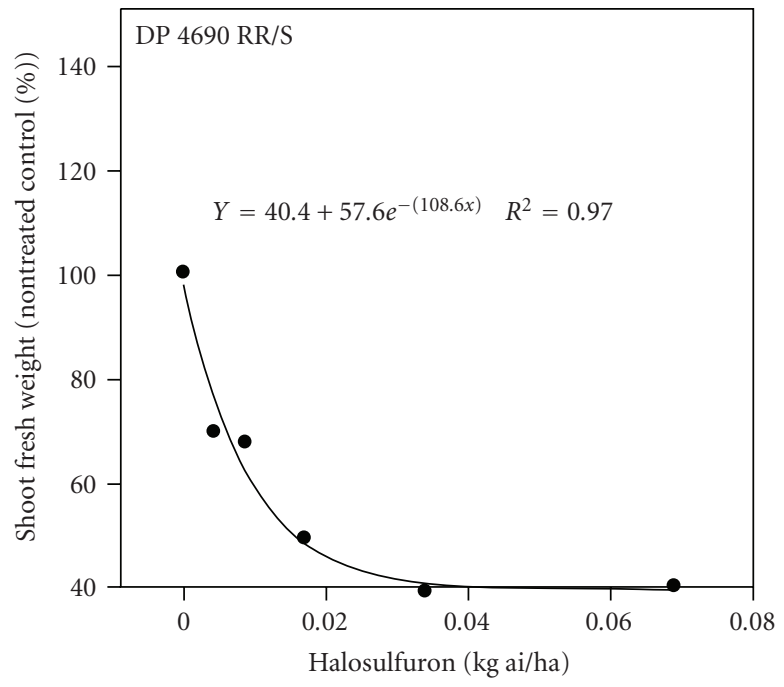

(j)

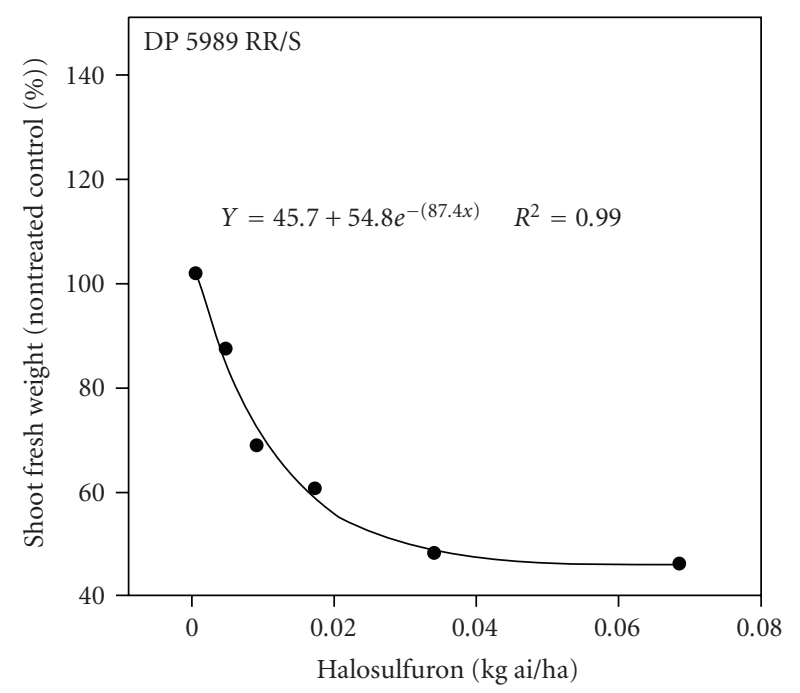

(k)

FIGURE 1: Varietal response of soybean to halosulfuron at 21 days after treatment. Shoot fresh weight expressed as percent of nontreated control. 
TABLE 2: Effect of halosulfuron on yield of soybean varieties with and without sulfonylurea- tolerant trait in the field studies conducted in Stoneville, Miss, USA in $2007^{a}$.

\begin{tabular}{|c|c|c|c|c|c|c|}
\hline \multirow{4}{*}{ Variety } & \multicolumn{6}{|c|}{ Field Study locations } \\
\hline & & USDA & \multirow{3}{*}{$\begin{array}{c}\text { Change }^{\mathrm{c}} \\
\%\end{array}$} & & MAFES & \multirow{3}{*}{$\begin{array}{c}\text { Change } \\
\%\end{array}$} \\
\hline & Nontreated & Treated $^{\mathrm{b}}$ & & Nontreated & Treated $^{\mathrm{b}}$ & \\
\hline & \multicolumn{2}{|c|}{$\mathrm{kg} / \mathrm{ha}$} & & \multicolumn{2}{|c|}{$\mathrm{kg} / \mathrm{ha}$} & \\
\hline DP $4112 \mathrm{RR} / \mathrm{S}$ & 3383 & 3222 & -4 & 2426 & 2321 & -4 \\
\hline DP $4888 \mathrm{RR} / \mathrm{S}$ & 3480 & 3491 & 0 & 3244 & 3107 & -4 \\
\hline DP 4919 RR/S & 3333 & 3292 & -1 & 2667 & 2397 & -10 \\
\hline 07-4492 RR/S & 4641 & 4288 & -7 & 3228 & 1788 & -45 \\
\hline DP $5115 \mathrm{RR} / \mathrm{S}$ & 3131 & 3055 & -2 & 2783 & 2307 & -17 \\
\hline DP $5335 \mathrm{RR} / \mathrm{S}$ & 2648 & 2829 & +7 & 2973 & 2846 & -4 \\
\hline DP $4748 \mathrm{~S}$ & 3555 & 3662 & +3 & 3163 & 2878 & -8 \\
\hline $\mathrm{P} 95 \mathrm{M} 90 \mathrm{RR} / \mathrm{S}$ & 3097 & 3217 & +4 & 3397 & 3214 & -5 \\
\hline AG 4903 RR/S & 3456 & 3479 & +1 & 3460 & 2660 & -23 \\
\hline DP $4690 \mathrm{RR}$ & 4169 & $\mathrm{ND}^{\mathrm{d}}$ & - & 2737 & 838 & - e $^{\mathrm{a}}$ \\
\hline DP 5989 & 3422 & ND & - & 2594 & 1973 & $-^{\mathrm{e}}$ \\
\hline t-test $(0.05)^{\mathrm{f}}$ & & & NS & & & NS \\
\hline $\operatorname{LSD}(0.05)^{\mathrm{g}}$ & & & NS & & & 18 \\
\hline
\end{tabular}

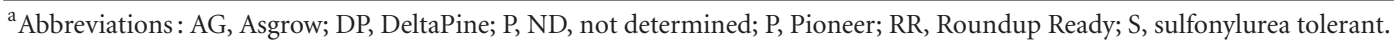

${ }^{\mathrm{b}}$ Soybean plants were treated postemergence with $0.034 \mathrm{~kg}$ ai/ha halosulfuron.

${ }^{c}$ Represents \% change in soybean yield in response to halosulfuron application. “+”and "-" signs indicate yield above and below the nontreated control, respectively, within varieties.

${ }^{\mathrm{d}}$ Yield not determined (ND) due to nonharvestable crop conditions resulting from extreme injury from halosulfuron.

${ }^{\text {e}}$ Yield change not included in analysis to be consistent with data reported for the USDA location.

"NS" indicates no significant effect of halosulfuron application on soybean yield according to the $t$ statistic $(P=.05)$ within individual varieties.

" "NS" (USDA) and 18 (MAFES) indicate no significant difference and significant difference, respectively, in \% yield change from halosulfuron application among soybean varieties according to Fisher's protected Least Significant Difference $(P=.05)$ procedure.

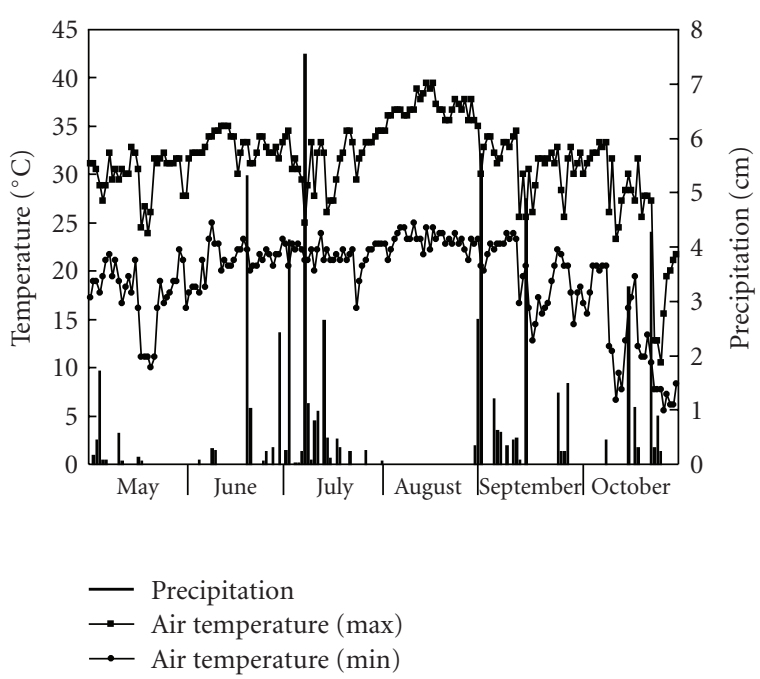

FIGURE 2: Air temperature and precipitation during the soybean growing season in 2007 at Stoneville, Miss, USA.

nontreated controls according to t-test results (Table 2). Differences in percent change in yield among ST varieties due to halosulfuron application were not significant based on LSD values (Table 2 ), with the percent change in yield ranging from $7 \%$ less than the nontreated control for 07 $4492 \mathrm{RR} / \mathrm{S}$ to $7 \%$ more than the nontreated control for DP
5335RR/S. Severe halosulfuron injury in two non ST varieties (DP 4690 RR and DP 5989) resulted in nonharvestable crop conditions leading to non determination of yield.

3.4. MAFES Site. All soybean varieties were injured to a certain extent by halosulfuron applied at $0.034 \mathrm{~kg} / \mathrm{ha}$ (data not shown). Varieties containing the ST trait were injured 2 to $5 \% 3 \mathrm{DAT}$ and 3 to $9 \% 7 \mathrm{DAT}$, but completely recovered by 14 DAT. The two non-ST varieties, DP 4690 RR and DP 5989 , were injured by halosulfuron 61 to $72 \% 3$ DAT, 39 to $40 \% 7$ DAT, 61 to $63 \% 14$ DAT, and 70 to $75 \% 28$ DAT (data not shown). Similar to the USDA site, halosulfuron did not reduce yield of all ST-trait containing varieties compared to their respective nontreated controls based on t-test results (Table 2). On the other hand, differences in percent change in yield among ST varieties due to halosulfuron application were significant based on LSD values (Table 2 ), with the percent change ranging from $4 \%$ to $45 \%$ less than the nontreated control. Among the ST varieties, 07-4492 RR/S and AG $490 \mathrm{RR} / \mathrm{S} 3$ were sensitive to halosulfuron. The variety $07-4492 \mathrm{RR} / \mathrm{S}$ was the most sensitive variety to halosulfuron and was also numerically the most affected on the USDA site. As with the USDA site, severe halosulfuron injury in two non-ST varieties (DP 4690 RR and DP 5989) resulted in yield loss.

In summary, the above results indicate that varieties with no ST-trait were sensitive to halosulfuron. Commercial 
soybean varieties with the ST-trait alone or both GR and ST traits stacked together can be planted in areas around rice fields and could tolerate halosulfuron drift from applications made in rice fields. Sensitivity of two varieties with ST trait (07-4492 RR/S and AG $4903 \mathrm{RR} / \mathrm{S}$ ) to halosulfuron at label use rates in field studies indicates a need for continuous evaluation of soybean varieties containing ST trait for their response to halosulfuron. Under conditions of limited land to grow crops, the only means to feed the growing population of the world is to increase productivity of the restricted hectares. One such approach is the cultivation of transgenic crops with pest related-resistant traits such as GR soybean. India and China remain the next large-scale adopters of GR soybean technology, after the American continent, wherein GR soybean would be cultivated in the proximity of rice. However, there exists a potential for injury to soybean from rice herbicides such as halosulfuron when grown adjacent to rice. Availability of GR soybean varieties stacked with an ST trait that provides tolerance to acetolactate synthase-inhibiting herbicides such as halosulfuron vastly eases the issue of soybean injury from halosulfuron. Further, halosulfuron could be an effective tool in the management of GR weeds in the US, Brazil, and Argentina.

\section{References}

[1] Anonymous, Gowan Company. Permit product information, October 2008, http://www.gowanco.com .

[2] S. A. Senseman, Ed., Herbicide Handbook, Weed Science Society of America, Lawrence, Kan, USA, 9th edition, 2007.

[3] USDA, National agricultural Statistics Service, United States Department of Agriculture, Washington, DC, USA, 2006.

[4] G. M. Dill, C. A. CaJacob, and S. R. Padgette, "Glyphosateresistant crops: adoption, use and future considerations," Pest Management Science, vol. 64, no. 4, pp. 326-331, 2008.

[5] FAO, International Rice Research Institute: United Nations Food and Agricultural Organization, Rome, Italy, 2007.

[6] K. Al-khatib and D. Peterson, "Soybean (Glycine max) response to simulated drift from selected sulfonylurea herbicides, dicamba, glyphosate, and glufosinate," Weed Technology, vol. 13, no. 2, pp. 264-270, 1999.

[7] C. E. Snipes, J. E. Street, and T. C. Mueller, "Cotton (Gossypium hirsutum) injury from simulated quinclorac drift," Weed Science, vol. 40, pp. 106-109, 1992.

[8] N. Bellaloui, K. N. Reddy, R. M. Zablotowicz, and A. Mengistu, "Simulated glyphosate drift influences nitrate assimilation and nitrogen fixation in non-glyphosate-resistant soybean," Journal of Agricultural and Food Chemistry, vol. 54, no. 9, pp. 3357-3364, 2006.

[9] C. J. Ellis and J. L. Griffin, "Soybean (Glycine max) and cotton (Gossypium hirsutum) response to simulated drift of glyphosate and glufosinate," Weed Technology, vol. 16, pp. 580$586,2002$.

[10] S. A. Sebastian, G. M. Fader, J. F. Ulrich, D. R. Forney, and R. S. Chaleff, "Semidominant soybean mutation for resistance to sulfonylurea herbicides," Crop Science, vol. 29, pp. 1403-1408, 1989.

[11] A. H. Anderson and F. W. Simmons, "Use of the sulfonylureatolerant soybean trait to reduce soybean response to prosulfuron soil residues," Weed Technology, vol. 18, pp. 521-526, 2004.
[12] K. N. Reddy and K. Whiting, "Weed control and economic comparisons of glyphosate-resistant, sulfonylurea-tolerant, and conventional soybean (Glycine max) systems," Weed Technology, vol. 14, no. 1, pp. 204-211, 2000.

[13] D. M. Simpson and E. W. Stoller, "Response of sulfonylureatolerant soybean (Glycine max) and selected weed species to imazethapyr and thifensulfuron combinations," Weed Technology, vol. 9, no. 3, pp. 582-586, 1995.

[14] W. R. Fehr, C. E. Caviness, D. T. Burmood, and J. S. Pennington, "Stage of development descriptions for soybeans, Glycine max (L.) Merrill,” Crop Science, vol. 11, pp. 929-931, 1971. 


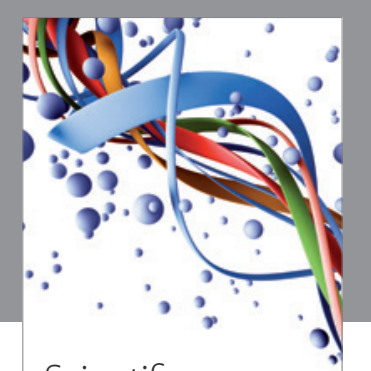

Scientifica
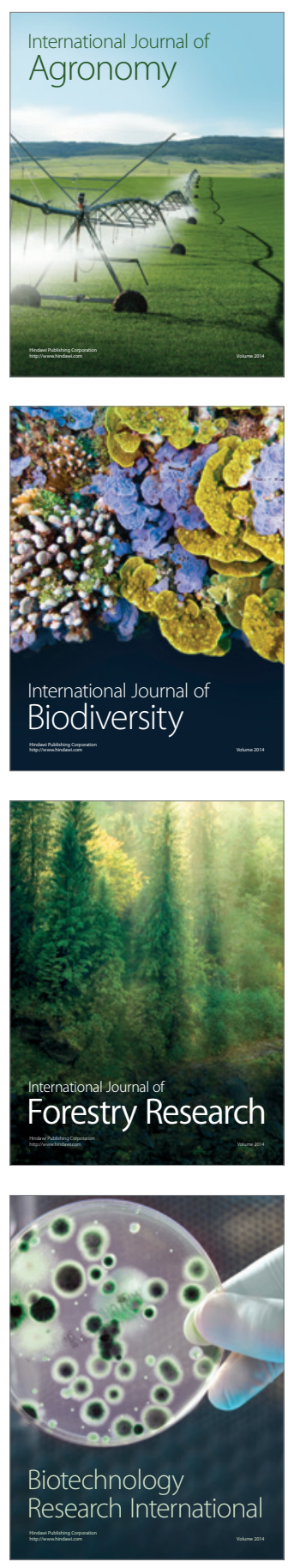
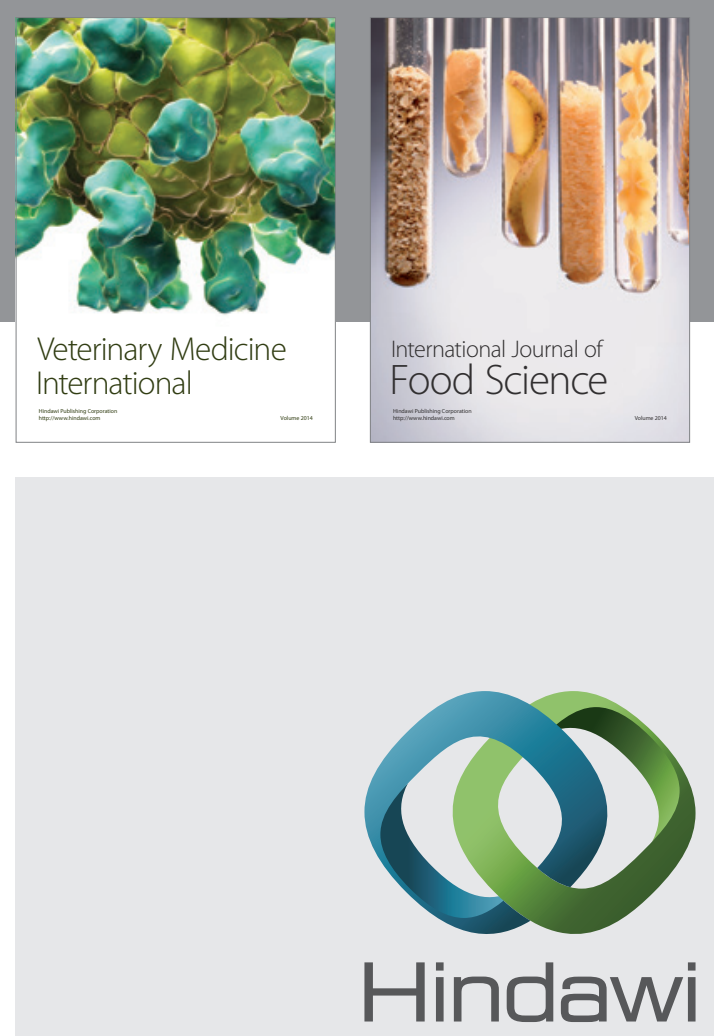

Submit your manuscripts at

http://www.hindawi.com
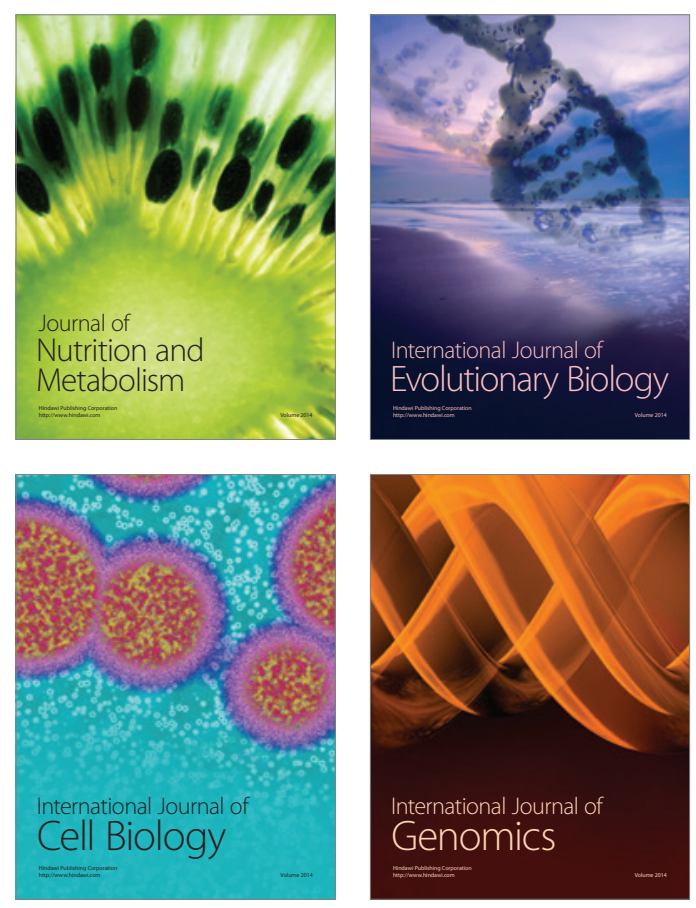
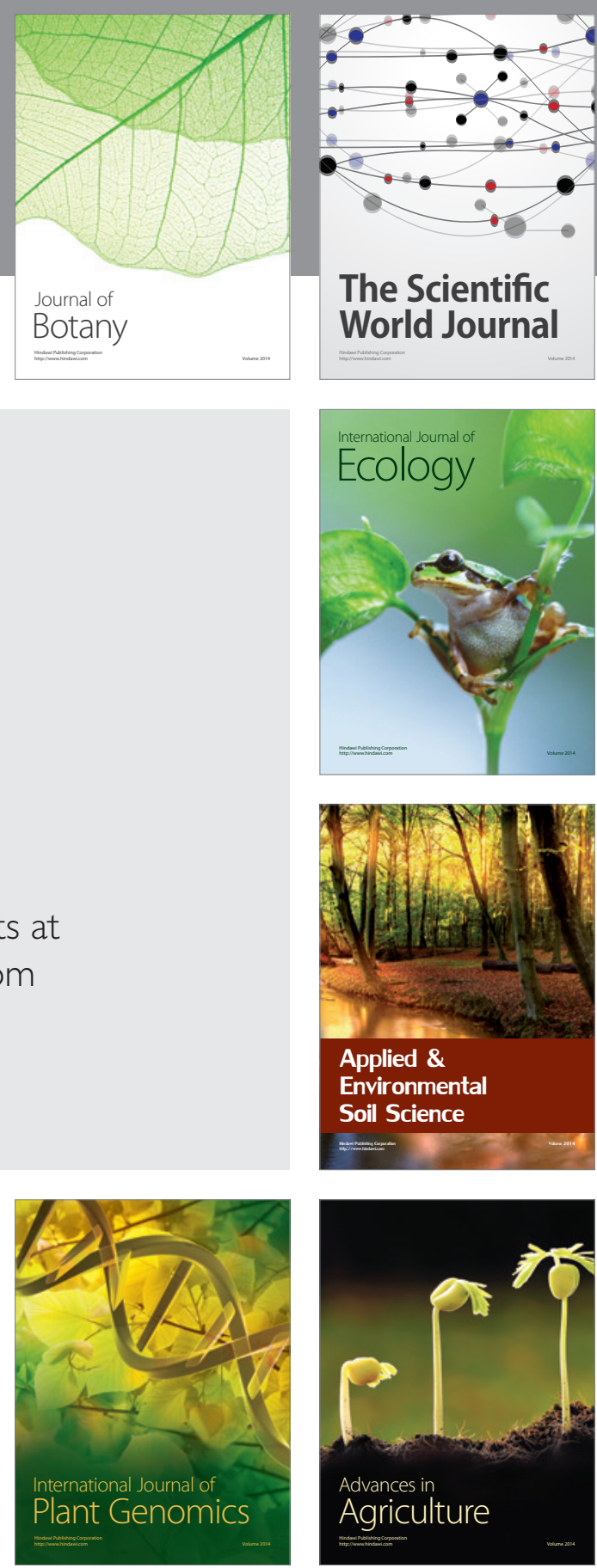

The Scientific World Journal
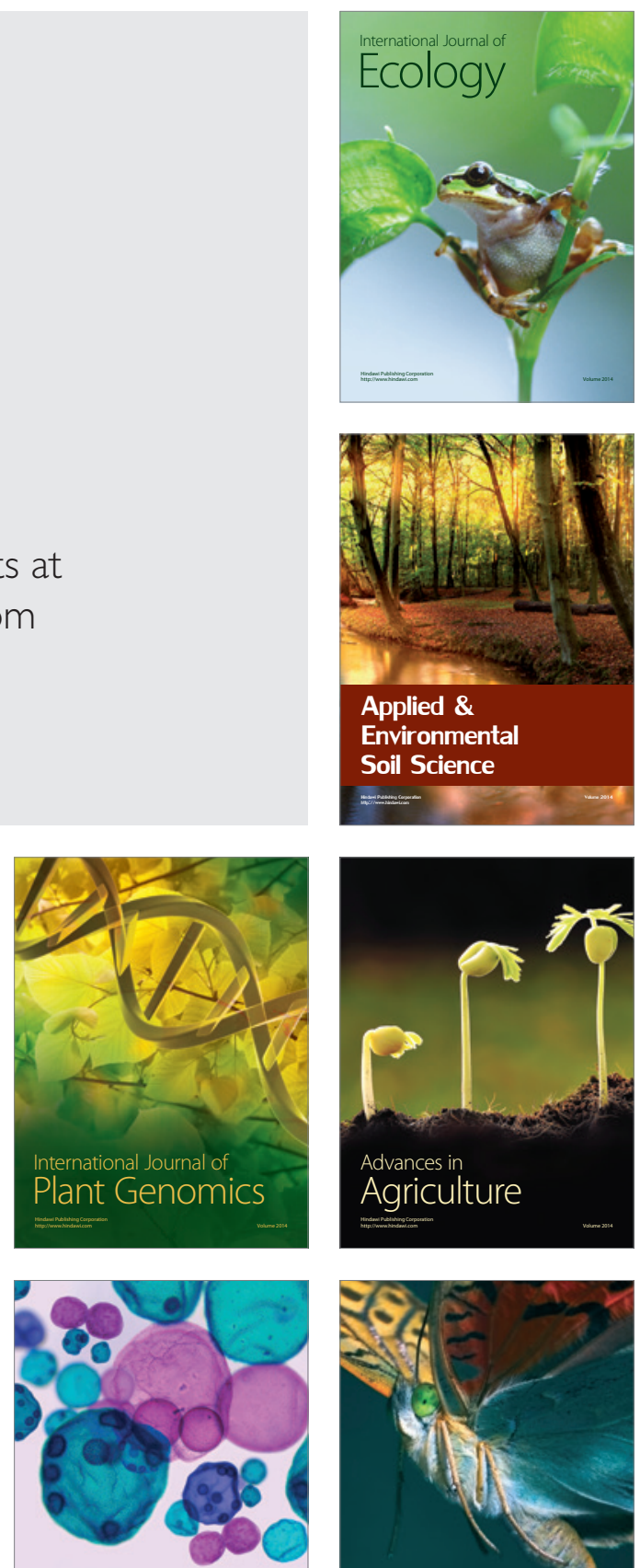

International Journal of Microbiology

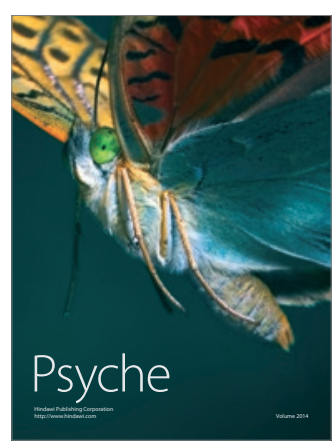

